\title{
The choice between bank debt and trade credit in business start-ups
}

Nancy Huyghebaert • Linda Van de Gucht • Cynthia Van Hulle

Published online: 3 August 2007

(C) Springer Science+Business Media B.V. 2007

Erratum to: Small Bus Econ (2007)

DOI: $10.1007 / s 11187-007-9068-8$

Please note that in the erratum both the title and the first author's name contain typos. The correct title and authors of this article should be:

The choice between bank debt and trade credit in business start-ups

Nancy Huyghebaert, Linda Van de Gucht and Cynthia Van Hulle

The online version of the original article can be found under doi: 10.1007/s11187-006-9005-2

N. Huyghebaert $(\bowtie) \cdot$ L. Van de Gucht $\cdot$ C. Van Hulle K.U. Leuven, Naamsestraat 69, Leuven 3000, Belgium e-mail: Nancy.Huyghebaert@econ.kuleuven.be 